\title{
MICROWAVE WOOD CHIP TREATMENT USE IN CHEMICAL PULP MANUFACTURING (TECHNICAL-ECONOMIC ASSESMENT)
}

\author{
A. Leshchinskaya \\ Plekhanov Russian University of Economics. 36 Stremyannyy Pereulok, 115093 Moscow, \\ Russia, \\ e-mail: alixfl@mail.ru]
}

\begin{abstract}
.
Low permeability of many wood species causes problems in the chemical pulp industry. These include: very long cooking times, high chemical consumption, large material losses, high energy consumption, and environment pollution. New microwave (MW) wood modification technology can provide an increase in wood permeability for liquids and gases that solves many of these problems. MW wood pre-treatment can increase pulp mill throughput, reduce chemical and power consumption, increase pulp quality and yield, and improve the environmental performance. Economic modelling of this new technology use in different chemical pulp mill conditions allowed to asses the effect of capital costs, electricity costs, labour costs and other cost components to specific total costs of MW chip processing. MW chip treatment costs for pulp mills with output 50,000 to 500,000 ait dry ton (ADT) per year at electricity cost range US\$0.04 to US\$0.24/kWh vary in the range from US\$17.7 to US\$60.8 per air dry ton of pulp. Electricity costs form the most significant part - 51- $69 \%$ of the total specific costs of MW chip processing at electricity costs US $\$ 0.08$ to US $\$ 0.12 / \mathrm{kWh}$. New technology application in different Russian conditions can provide benefits up to $7-22$ Mil US\$ per year for pulp mills with output more than 200,000 ADT/year. Ecological effect and high economic advantages of this MW technology provide good opportunity for commercialisation.
\end{abstract}

Keywords: chemical pulping, microwave wood modification, pulp, softwood, wood chips.

\section{Introduction}

The global production of pulp in the world is around 180 mil tons per year [3]. USA is the most significant pulp manufacturer producing 50 mil tons per year. The volumes of pulp products in Russia over the last few years has increased by $5.2-6.9 \%$ per year and reached 8.1 mil tons in 2017. The consumption of pulp and paper products is growing steadily in the world. A quarter of the pulp produced in Russia is for export. Therefore, it is necessary to use advanced knowledge-based technologies in pulp industry, which Russian Government provides funding for development and commercialization of such technologies.

Large volumes of cellulose are produced from wood chips using chemical methods which have many shortcomings: high energy and chemical consumption, significant raw material losses, and high level of environment pollution [4]. One of the new technologies is microwave wood structure modification technology [7] which changes wood properties and radically increases wood permeability by liquids and gases. Industrial application of this technology can significantly improve technological processes of the pulp production leading to great economic and ecological benefits. 


\section{Technology}

The MW wood modification technology works in the following way. Intensive MW power applied to green wood generates steam pressure within the wood cells. High internal pressure destroys the weak elements of wood structure, opens pores and forms micro and macro cracks. A several thousand-fold increase in wood permeability can be achieved in species previously found to be impermeable by liquids and gases. Fig. 1 demonstrates how MW modification changes wood structure and converts wood to a highly porous material: the left side of the sample - wood before modification, the right side - after modification with a lot of visible and invisible voids.

Fig 1. Wood sample after intensive MW modification. Left side - natural wood, right side MW modified wood.

MW wood modification significantly increases the speed of the pulp cooking and improves the production processes. The MW technology $[1,2,7]$ showed potential improvements in the pulp industry through:

- increase in mill throughput

- $\quad$ significant reduction of chemical consumption

- significant reduction of power consumption

- increase in pulp quality and yield

- improvement of environmental performance.

One of the proposed pulp process schemes with chip MW treatment is shown in Fig 2.

1

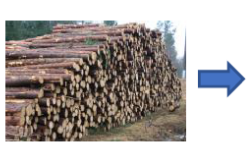

4

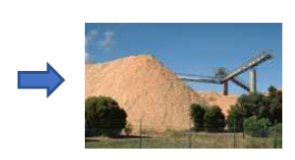

7

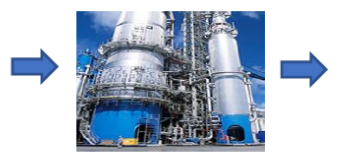

2

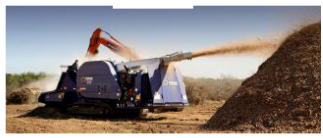

5

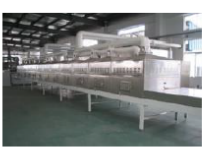

8

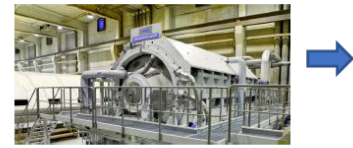

3

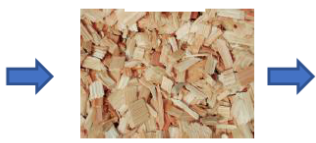

6

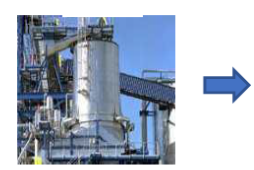

9

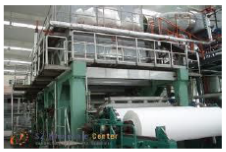

Fig 2. Pulp manufacturing process scheme. 1 - logs, 2 - chipping, 3 - chips for pulping, 4 chip storage, 5- chip MW treatment, 6 - steaming, 7 - cooking, 8 - washing, 9 - pulp making. 
In addition, the raw material can be in the form of large chips, wood pieces, parts of boards or logs. MW wood modification technology can be used by pulp mills with batch and continuous digesting and not limited by mill throughput.

\section{New process advantages}

The potential impacts and benefits of chemical pulp manufacturing using this new MW technology was assessed in Oak Ridge National Laboratory $[1,2,8]$ and University of Melbourne [7] and outlined in the Table 1.

Table 1. Microwave technology benefits.

\begin{tabular}{|l|l|}
\hline Potential impacts & Benefits \\
\hline Increase in throughput & $\begin{array}{l}20-34 \% \text { increase in throughput for digester- } \\
\text { limited mills }\end{array}$ \\
\hline $\begin{array}{l}\text { Chemical savings } \\
\text { (increased speed of } \\
\text { chemical chip cooking } \\
\text { reactions) }\end{array}$ & $\begin{array}{l}\text { on chemical recovery processes, especially lime kiln } \\
\text { and recover boiler }\end{array}$ \\
\hline Material savings & $\begin{array}{l}\text { Reject reduction from } 3.8 \text { to } 0.3 \% \\
\text { Screened pulp yield increase } 2.7 \%\end{array}$ \\
\hline $\begin{array}{l}\text { Larger chip size can be } \\
\text { utilised as pulping liquor is } \\
\text { more readily absorbed }\end{array}$ & $\begin{array}{l}\text { Reduction of wood loses associated with } \\
\text { oversize chips } \\
2 \% \text { increase in pulp strength due to fewer cut } \\
\text { fibres from chipping }\end{array}$ \\
\hline $\begin{array}{l}\text { Environmental aspects } \\
\text { Improved environmental performance due to } \\
\text { reduction of fuel usage }\end{array}$ \\
\hline
\end{tabular}

MW modified wood has a more even structure meanings that pulping chemicals are absorbed more evenly, thereby cooking more consistently. This means less variation in the degree of cooking across the chip, and therefore less quality variations due to overcooking or undercooking. Handsheet properties of the pulp from MW modified wood are comparable to the properties of the pulp from untreated wood. An increase in the length of chip will reduce the number of cut fibres, improving the yield of longer fibres by reducing the proportion of fines. Both microwave modified hardwood and softwood can be used for pulping.

MW technology reduces chemical, energy and raw material consumption in pulp production. This allows the chemical pulp mills to significantly reduce pollution loads to the environment.

\section{Microwave plant parameters and costs}

Softwood microwave modification requires less energy and provides lower costs compared to hardwoods, therefore the first cost estimation was done for softwoods. The MW plant power required for pulp mills with different throughput, electric energy consumption, and MW plant costs are outlined in Table 2. All specific data of pulp units is in ADT (air dried ton) and calculations are based on world prices of MW equipment (MW generators with frequency $0.922(0.915) \mathrm{GHz})$. All costs are in US\$. 
Table 2. MW power plant parameters and costs.

\begin{tabular}{|c|l|l|l|l|}
\hline $\begin{array}{l}\text { Plant output, } \\
\text { ADT(air dry } \\
\text { ton) /year }\end{array}$ & $\begin{array}{l}\text { Output, } \\
\text { ADT/hour } \\
\text { (7500 working } \\
\text { hours per } \\
\text { year) }\end{array}$ & $\begin{array}{l}\text { Microwave } \\
\text { plant power, } \\
\mathrm{kW}\end{array}$ & $\begin{array}{l}\text { Electric energy } \\
\text { consumption, } \\
\mathrm{kWh} / \mathrm{ADT}\end{array}$ & $\begin{array}{l}* \text { MW plant } \\
\text { cost (only } \\
\text { technological } \\
\text { equipment } \\
\text { cost), US\$ }\end{array}$ \\
\hline 50,000 & 6.7 & 1000 & 192 & $1,665,000$ \\
\hline 100,000 & 13.3 & 2000 & 192 & $3,330,000$ \\
\hline 200,000 & 26.6 & 4000 & 192 & $6,290,000$ \\
\hline 500,000 & 66.7 & 10200 & 192 & $14,688,000$ \\
\hline
\end{tabular}

* MW plant costs in the Table 3 include only technological equipment (MW generators, applicators, mechanical, electrical facilities) and do not include buildings.

Economic modelling of this technology application has been done for pulp mill throughput range 50,000 to 500,000 ADT/year, 3 working shifts per day (930 shifts per year) and electricity cost range $\$ 0.04$ to $\$ 0.24 / \mathrm{kWh}$. Microwave plants were operated by workers (not automatic).

\section{Costs of microwave chip treatment}

The cost assessment was based on analysis of specific MW treatment costs which include capital costs (depreciation rate 17\%), energy, maintenance, magnetron replacement costs, and labour costs. The specific costs do not include building, electrical connections, mechanical installation, on costs (overheads) and taxes.

MW chip processing costs depends significantly from capital costs, electricity and labour costs. Fig. 3 shows a dependence of MW treatment specific costs on electricity costs at different sawmill throughput.

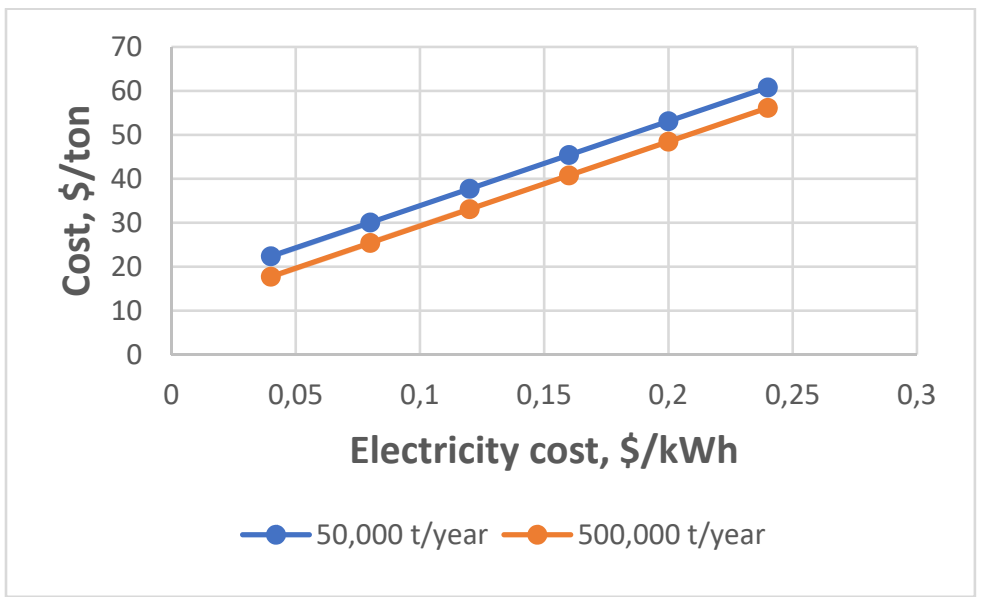

Fig. 3. Specific MW chip treatment costs depending on electricity costs at pulp mill output 50,000 and 500,000 ADT/year.

The electricity cost increase from $\$ 0.04$ to $\$ 0.24 / \mathrm{kWh}$ provides specific MW processing cost rise by 2.7 to 3.1 times at pulp mill output range of 50,000 to 500,000 ADT/year. 
Effect of the pulp mill throughput on MW treatment specific costs is shown in Fig. 4. Throughput increase lowers costs because the portion of the capital and labour costs are reduced in the total specific costs.

An increase in the pulp mill throughput from 50,000 to 500,000 ADT/y at electricity cost range $\$ 0.04$ to $\$ 0.24 / \mathrm{kWh}$ reduces specific MW treatment costs by 21 to $8 \%$. Specific cost components: capital cost (CC), magnetron replacement cost (RC), maintenance cost (MC), electricity cost (EC), labour cost (LC) at pulp mill output from 50,000 to 500,000 ADT/year at electricity cost $\$ 0.12 / \mathrm{kWh}$ are shown in Fig. 5.

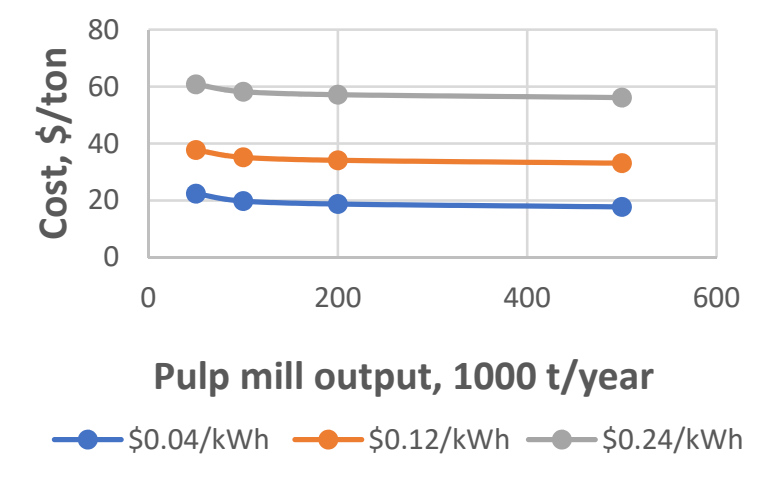

Fig. 4. Specific MW chip treatment costs depending on pulp mill output at electricity cost $\$ 0.04,0.12$ and $\$ 0.24 / \mathrm{kWh}$.

Electricity costs form the most significant part of the total specific costs of MW processing. Electricity costs (at electricity price $\$ 0.12 / \mathrm{kWh}$ ) form $62-69 \%$ of the total specific costs. Capital costs form $15-16 \%$ of the total specific costs. Labour costs form $5-14 \%$ of the total specific costs. At electricity price of $\$ 0.08 / \mathrm{kWh}$ the electricity costs form $51-60 \%$, capital costs $-19-20 \%$, labour costs - 6-18\% of the total specific costs of MW treatment.

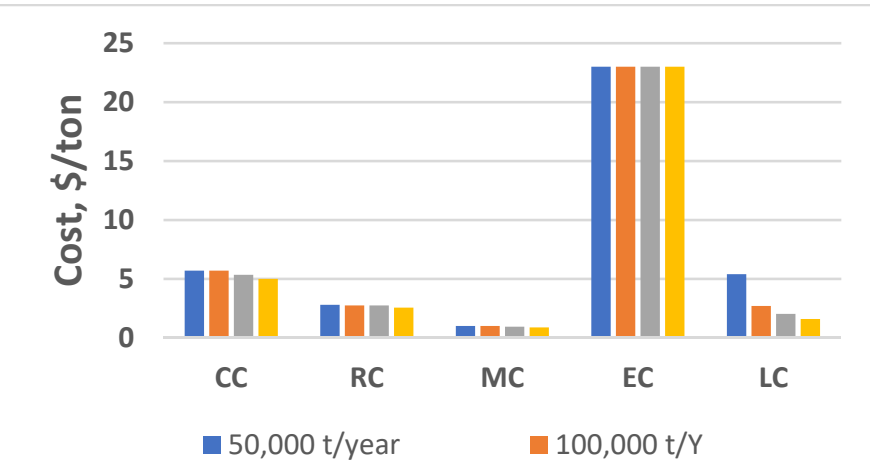

Fig. 5. Specific cost components: CC- capital cost, RC- magnetron replacement cost, MC - maintenance cost, EC- electricity cost, LC- labour cost, at pulp mill output from 50,000 to $500,000 \mathrm{ADT} /$ year at electricity cost $\$ 0.12 / \mathrm{kWh}$. 


\section{Results}

MW chip treatment costs for pulp mills with output 50,000 to 500,000 t/year at electricity cost range $\$ 0.04$ to $\$ 0.24 / \mathrm{kWh}$ vary in the range from $\$ 17.7$ to $\$ 60.8$ per air dry ton of pulp. Electricity costs form the most significant part of the total specific costs of MW chip processing. They form $62-69 \%$ of the total specific costs of MW processing at electricity price $\$ 0.12 / \mathrm{kWh}$. Capital costs forms $15-16 \%$, labour costs forms $5-14 \%$ of the total specific costs. At electricity price $\$ 0.08 / \mathrm{kWh}$ the electricity costs form $51-60 \%$, capital costs - 19$20 \%$, labour costs $-6-18 \%$ of the total specific costs of MW treatment.

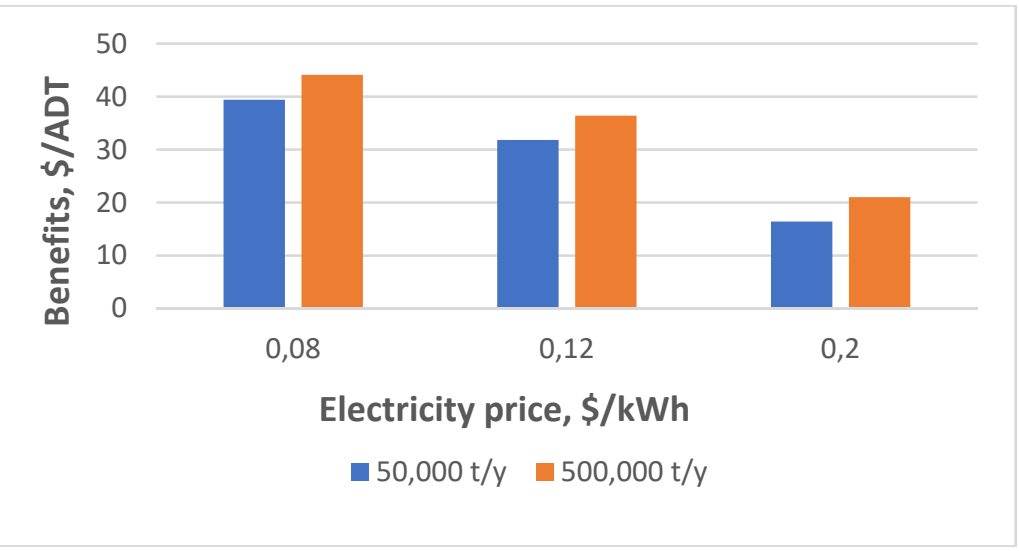

Fig.6. New MW technology benefits depending on electricity costs and pulp mill output.

Cost savings connected with advantages of MW technology use in chemical pulp production (outlined in Table1)

make up $\$ 65.0$ per air dry tone (ADT) of pulp for softwoods (this value does not include larger chip size usage, water use reduction and other environment aspects). Depending on electricity costs in the range of $\$ 0.08$ to $\$ 0.20 / \mathrm{kWh}$ (after withdrawal costs associated with MW treatment) the benefits of applying the new technology application range from $\$ 44$ to \$16/ADT (Fig.6).

Economic modelling of MW technology application in different Russian conditions, depending on mill throughput, raw material, chemical costs, energy costs, and capital costs, gave the following benefits for pulp mill with output 50,000 to 500,000 ADT/year at world pulp price US\$860/ADT:

\begin{tabular}{|c|c|c|c|}
\hline \multirow{2}{*}{$\begin{array}{c}\text { Pulp mill } \\
\text { output, } \\
\text { ADT/year }\end{array}$} & \multicolumn{3}{|c|}{ Electricity price, $\$ / \mathrm{kWh}$} \\
\cline { 2 - 4 } & 0.08 & 0.12 & 0.20 \\
\hline 50,000 & 2.0 & 1.6 & 0.8 \\
\hline 100,000 & 4.2 & 3.4 & 1.9 \\
\hline 200,000 & 8.6 & 7.1 & 4.0 \\
\hline 500,000 & 22.1 & 18.2 & 10.5 \\
\hline
\end{tabular}

It is difficult to assess ecological advantages in dollars because they are determined on the individual conditions of the chemical pulp mill. Developed by the author, "Methodology of Knowledge-based High Technology Financing" [5] outlines the mechanism for making optimal decisions in concrete conditions for technology commercialization. 


\section{Conclusions}

MW wood modification technology use in chemical pulping provides significant advantages: increase in mill throughput, reduction of chemical and power consumption, increase in pulp quality and yield, improvement of environmental performance. Specific costs of softwood chip processing in MW plant at electricity costs $\$ 0.08-\$ 0.12 / \mathrm{kWh}$ are $\$ 25.4-\$ 33.7$ /ADT of pulp. Electricity costs form the most significant part of the total specific costs of MW processing and form 51-69\% share in the total specific costs at electricity prices $\$ 0.08$ to $\$ 0.12 / \mathrm{kWh}$. At the same conditions capital costs form $15-20 \%$ share, labour costs forms $5-18 \%$ share of the total specific costs. The electricity cost increase from $\$ 0.04$ to $\$ 0.24 / \mathrm{kWh}$ leads specific MW processing cost rise by 2.7 to 3.1 times at pulp mill output range 50,000 to 500,000 ADT/year.

New technology application in different Russian conditions can provide a significant reduction in the softwood chemical pulp production costs and result in profit up to $7-22$ Mil US\$ per year for pulp mills with output more 200,000ADT/year at electricity costs $\$ 0.08-0.12 \$ / \mathrm{kWh}$. High economic advantages of this microwave technology application in pulp and paper industry recommend it for commercialisation. The technology can be used by pulp mills with batch and continuous digesting and not limited by mill throughput.

\section{References}

1. Compere A. L. et al. Increasing yield and quality of low-temperature, low-alkali kraft cooks with microwave pretreatment. US Department of Energy. Industrial Technologies Program. FY06 ITP Forest Products Portfolio Peer Review. April 56, 2006. Atlanta, Georgia, USA. Presentation. 19 pp. 2006.

2. Compere A. L. et al. Microwave Pretreatment to Decrease Pulping Energy and Chemicals. TAPPI Pulping Conference, 7 pp. 2007, www.tappi.org/Downloads/unsorted/UNTITLED--PS0442pdf.aspx

3. FAO Statistics. Yearbook of Forest Products. 2016. http://www.fao.org/3/ai7304m.pdf. Pages 144-145.

4. Lagutina T F., Bogolitsin K G., Gusakova M A., Ecological assessment of pulp mill activities in cellulose paper industry. Prospect ways of waste utilization. Journal of Russian Chemical Society (Mendeleev's name) LV (1), UDK 574-676, 2001. 5. Leshchinskaya A. F. Methodology of Knowledge-based High Technology

Financing. RGTEU, Moscow. ISBN 978-5-87827-506-4 (UДК 336.645.1 L54), 2012

6. Oak Ridge National Laboratory. Industrial Technologies Program. Completed R\&D. Increasing Yield and Quality of Low-Temperature, Low-Alkali Kraft Cooks with Microwave Pretreatment, 2007, http://www.ornl.gov/sci/ees/itp/CompletedRD.shtml.

7. Torgovnikov G. and Vinden P., Microwave wood modification technology and its applications. Forest Products Journal. 2010, Vol 60, (4), 173-182.

8. US Department of Energy. Industrial Technologies Program. Forest Products.. Increasing yield and quality of low-temperature, low-alkali kraft cooks with microwave pretreatment. Project Fact Sheet. pp. 1-2. 2007. 